\title{
Evaluation of the fourth ventricle and nomogram of intracranial translucency at 11-13 weeks of gestation
}

\author{
Derya Sivri Aydın', Murat Yayla² \\ ${ }^{1}$ Department of Obstetrics and Gynecology, Haseki Training and Research Hospital, Health Science University, Istanbul, Turkey \\ ${ }^{2}$ Perinatology Clinic, International Hospital, Istanbul, Turkey
}

\begin{abstract}
Objective: The aim of this study was to evaluate normal reference ranges of intracranial translucency (IT) diameter, and to obtain its nomogram in normal fetuses, during 11-13 weeks of gestation.

Methods: This was a retrospective data evaluation of first trimester ultrasound scans. A total of 2417 singleton pregnancies were included in the study. IT was measured in the nuchal translucency plane. Nomogram and formula of IT diameter were defined according to crown-rump length (CRL).

Results: The IT diameters were measured successfully in 2250 fetuses $(93.1 \%)$. The mean maternal age was $31.8 \pm 4.0$ years. The mean CRL was $62.0 \pm 6.9 \mathrm{~mm}$. The mean IT diameter was $1.83 \pm 0.29$ $\mathrm{mm}$. The linear tendency was determined according to the following formula: IT $(\mathrm{mm})=0.54+0.02 \times \operatorname{CRL}(\mathrm{mm}) ; \mathrm{r}^{2}=0.24$.

Conclusion: We presented the feasibility and a nomogram of IT diameter at 11 to $13^{+6}$ weeks of gestation in our population to be used for early prediction of neural tube defects.
\end{abstract}

Keywords: Fourth ventricle, intracranial translucency, nomogram.

\section{Introduction}

Central nervous system (CNS) malformations are the second most common category of congenital anomalies after congenital heart disease. Prenatal diagnosis of spina bifida and other neural tube defects (NTDs) is a relevant issue in modern antenatal care. Most of them are detectable by maternal serum alpha-fetoprotein or anomaly screening after first trimester. ${ }^{[1]}$ Fetal head's sonographic findings

\section{Özet: 11-13. gebelik haftalarında dördüncü ventrikülün değerlendirilmesi ve intrakraniyal saydamlık nomogramı}

Amaç: Bu çalışmanın amacı 11-13. gebelik haftalarında normal fetüslerde intrakraniyal saydamlık (IT) çapının normal referans aralıklarını saptamak ve nomogramını elde etmektir.

Yöntem: Bu çalışma ilk trimester ultrason taramasının retrospektif bir data değerlendirmesidir. Bu çalışmaya tekiz 2417 gebelik dahil edildi. Ense saydamlığı planında IT ölçüldü. Baş-popo uzunluğuna (CRL) göre IT çapının formülü ve nomogramı oluşturuldu.

Bulgular: IT çapı 2250 fetüste (\%93.1) başarılı bir şekilde ölçüldü. Ortalama anne yaşı $31.8 \pm 4.0$ yıldı. Ortalama CRL $62.0 \pm 6.9$ mm idi. Ortalama IT çapı $1.83 \pm 0.29 \mathrm{~mm}$ idi. Doğrusal eğilim aşağıdaki formüle göre belirlendi: IT $(\mathrm{mm})=0.54+0.02 \times \mathrm{CRL}(\mathrm{mm})$; $\mathrm{r}^{2}=0.24$.

Sonuç: Nöral tüp defektlerinin erken tanısında kullanılmak üzere popülasyonumuza ait $11-13^{+6}$ hafta gebeliklerde IT ölçümü uygulanabilirliğini ve IT nomogramını sunduk.

Anahtar sözcükler: Dördüncü ventrikül, intrakranyal saydamlık, nomogram.

such as "lemon-shaped" head and a "banana-shaped" cerebellum and "hydrocephalus" have been well-established in the second trimester. However, these signs may be subtle or even absent in the first trimester. ${ }^{[2,3]}$ Only a few cases of spina bifida can be detected before 12 weeks of gestation by noting irregularities of the bony spine or a bulging within the posterior contour of the fetal back ${ }^{[4]}$ or by the measurements of biparietal diameter. ${ }^{[5]}$
Correspondence: Derya Sivri Aydın, MD. Gynecology and Obstetrics Clinic, Haseki Training and Research Hospital, Istanbul, Turkey. e-mail: deryasivri@hotmail.com Received: June 28, 2018; Accepted: August 17, 2018

Please cite this article as: Sivri Aydin D, Yayla M. Evaluation of the fourth ventricle and nomogram of intracranial translucency at 11-13 weeks of gestation. Perinatal Journal 2018;26(2):102-105.

(C2018 Perinatal Medicine Foundation
Available online at: www.perinataljournal.com/20180262009 doi: $10.2399 /$ prn. 18.0262009 QR (Quick Response) Code:

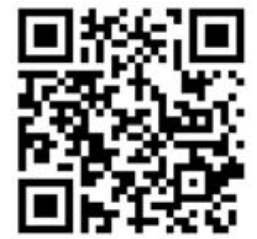


Screening at 11 to $13^{+6}$ weeks of gestation is now performed not only for the measurement of nuchal translucency (NT), but also for detecting severe malformations including open NTDs. The fourth ventricle, which presents as an intracranial translucency (IT), is easily demonstrated in the mid-sagittal view of the fetal face used for measurement of NT ${ }^{[6]}$ After the IT measurement was defined, it became a part of the sonographic evaluation at $11-13^{+6}$ weeks of gestation. ${ }^{[7-12]}$

Since June 2011, we have introduced the measurement of IT diameter during first trimester scanning into our routine practice. Consequently, in this study, we aimed to visualize and obtain the reference ranges of IT diameter according to fetal crown-rump length (CRL) in our population and to obtain a local IT nomogram.

\section{Methods}

This study was a retrospective descriptive case series of first trimester ultrasound scans of 2531 fetuses of singleton pregnancies. All chromosomal abnormalities $(\mathrm{n}=$ 53), cardiac anomalies $(\mathrm{n}=20)$, CNS anomalies $(\mathrm{n}=19)$, lung abnormalities $(n=13)$, extremity anomalies $(n=5)$ and other system anomalies $(n=4)$ were excluded from the study which were determined by either first or second trimester screening, and 2417 fetuses were included in this study. All evaluations and measurements were performed by a single operator (MY) during 11-13week NT scan without prolonging the scanning time. The posterior brain was examined in the mid-sagittal view as defined by Chaoui et al. ${ }^{[6]}$ at the first trimester screening of consecutive single pregnant women between July 2011 and December 2017. The scans were performed transabdominally using Voluson 730 Expert, E8 and E10 (General Electric, Chicago, IL, USA). When the nuchal translucency was not visualized transabdominally, a transvaginal scan was performed. In the same mid-sagittal view of the fetal face as used for measurement of NT and nasal bone, fourth cerebral ventricle (IT) was visible and measured (Fig. 1). A total of 2250 cases of which IT diameters could be measured were analyzed for this study. Postnatal outcomes were available. Biometric evaluation of all fetuses was performed by CRL and other routine parameters. According to CRL, the fetuses were divided into four groups as CRL 45-54 mm was Group 1, CRL 55-64 mm was Group 2, CRL 65-74 mm was Group 3, and CRL 75-84 mm was Group 4. The mean and standard deviation were calculated for IT diameter according to

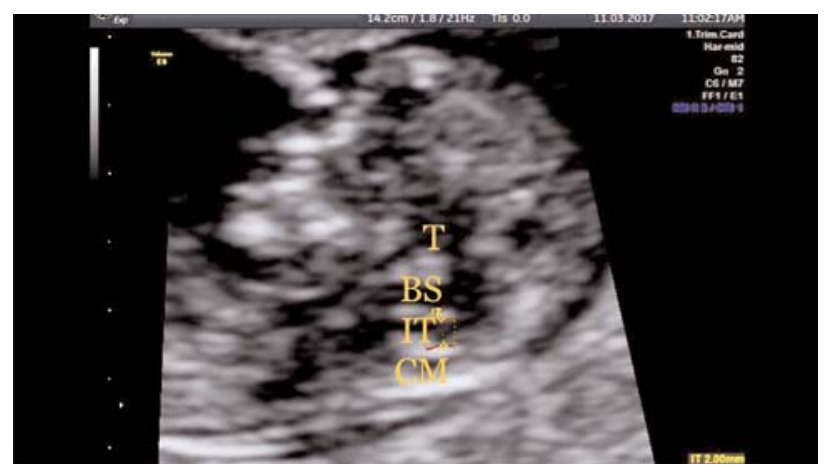

Fig. 1. Ultrasound image in the mid-sagittal plane of the fetal face showing thalamus (T), brain stem (BS) and cisterna magna (CM). The fourth ventricle presents as intracranial translucency (IT) between the BS and the choroid plexus.

CRL groups. Nomograms and formula of IT diameter were obtained according to CRL.

\section{Statistical method}

Statistical analyses were performed using SPSS (Version 16; SPSS Inc., Chicago, IL, USA). Descriptive statistics were performed for all variables as appropriate. Mean and standard deviations of IT diameter were calculated according to groups. Linear regression analyses were used to determine the association between IT diameter and other biometric parameters.

\section{Results}

The mean maternal age was $31.8 \pm 4.0$ years, and the mean CRL was $62.0 \pm 6.9 \mathrm{~mm}$. The IT diameters were measured successfully in 2250 fetuses (93.1\%). Maternal obesity, lack of available plane for IT visualization, early weeks of gestation and inadequate time for expanding examination were the main causes of the lacking measures. The mean IT diameter for the $11-13^{+6}$ weeks of gestation was $1.83 \pm 0.29 \mathrm{~mm}$, the mean values of IT diameters according to CRL ranges are shown in Table $\mathbf{1}$ and the mean

Table 1. The mean of IT diameter according to CRL ranges.

\begin{tabular}{lccc} 
CRL $(\mathbf{m m})$ & Mean \pm SD $(\mathbf{m m})$ & $\mathbf{n}$ & $\%$ of total $\mathbf{n}$ \\
\hline $45-54$ & $1.60 \pm 0.24$ & 305 & 13.6 \\
$55-64$ & $1.79 \pm 0.25$ & 1145 & 50.9 \\
$65-74$ & $1.96 \pm 0.27$ & 711 & 31.6 \\
$75-84$ & $2.12 \pm 0.29$ & 89 & 4.0 \\
\hline Total & $1.83 \pm 0.29$ & 2250 & 100.0 \\
\hline
\end{tabular}

CRL: crown-rump length; IT: intracranial translucency. 
Table 2. The IT diameter percentiles by CRL groups.

\begin{tabular}{lcccccccc} 
& \multicolumn{10}{c}{ Percentiles } \\
\cline { 2 - 10 } Mean IT diameter (mm) & CRL & $\mathbf{5}$ & $\mathbf{1 0}$ & $\mathbf{2 5}$ & $\mathbf{5 0}$ & $\mathbf{7 5}$ & $\mathbf{9 0}$ & $\mathbf{9 5}$ \\
& $\mathbf{4 5 4}$ & 1.2 & 1.3 & 1.4 & 1.6 & 1.7 & 1.9 & 2.0 \\
& $55-64$ & 1.4 & 1.5 & 1.6 & 1.8 & 1.9 & 2.1 & 2.2 \\
& $65-74$ & 1.5 & 1.6 & 1.8 & 1.9 & 2.1 & 2.3 & 2.4 \\
& $75-84$ & 1.7 & 1.8 & 1.9 & 2.1 & 2.3 & 2. & 2.6 \\
\hline
\end{tabular}

CRL: crown-rump length; IT: intracranial translucency.

values of IT diameters according to percentiles are shown in Table 2.

Minimum and maximum IT measurements were ranged between $1.2 \mathrm{~mm}$ and $2.6 \mathrm{~mm}$ (5th and 95th percentiles) during $11-13^{+6}$ weeks. IT diameter increased linearly with CRL from a mean of $1.6 \mathrm{~mm}$ at CRL $45-54 \mathrm{~mm}$ to $2.1 \mathrm{~mm}$ at CRL $75-84 \mathrm{~mm}(\mathrm{p}<0.0001)$. There was a significant increase in IT diameter with increasing CRL $(\mathrm{p}<0.001)$. A weak positive correlation was determined between IT and CRL according to the following formula: IT $(\mathrm{mm})=0.54+0.02 \times \mathrm{CRL}(\mathrm{mm})$; $r^{2}=0.24$ (Fig. 2).

\section{Discussion}

Spinal dysraphism or spina bifida refers to protrusion of the spinal contents through a bone defect in the spine. Most of the spinal dysraphic defects (80-85\%) are open defects and are detectable by maternal serum alpha-fetoprotein screening or by ultrasonography after first trimester. The remaining 10 to 15 percent of them are

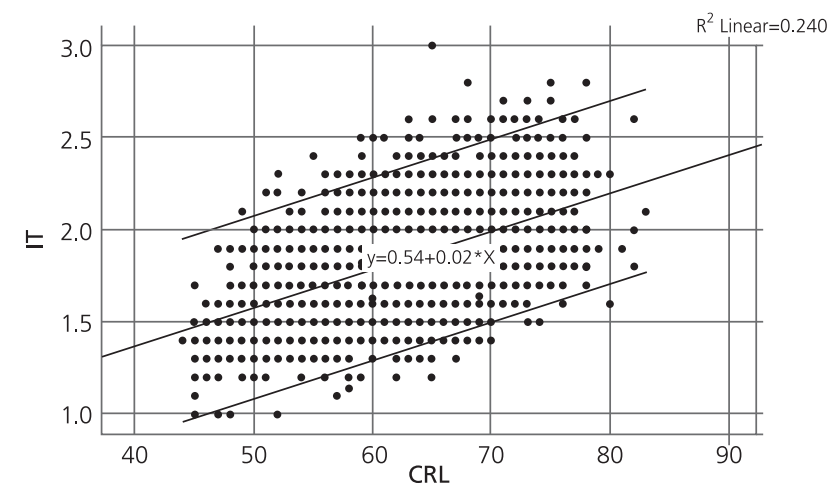

Fig. 2. Reference range (mean, 5th and 95th percentiles) of IT diameter according to CRL (CRL: crown-rump length, IT: intracranial translucency). closed by normal skin covering the bone defect. Approximately 80 percent of lesions are in the lumbar, thoracolumbar, or lumbosacral areas of the spine, and the remaining lesions are in the cervical and sacral areas. ${ }^{[1]}$

Since the banana and lemon signs cannot be relied upon at first trimester, the fourth ventricle, which presents as an IT between the brain stem and choroid plexus, was first suggested in 2009 and its compression was defined as a possible marker for the detection of open spina bifida. ${ }^{[6]}$ Non-visualization of the cisterna magna and posterior shift of the brain stem towards the occipital bone have also been described as early signs of open spina bifida. ${ }^{[7,8]}$ In open NTD, IT is not measurable in $18 \%$, and is under the 1 st percentile in $45 \%$ of the cases. $^{[7]}$ Paradoxically, IT is enlarged in Blake's pouch

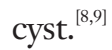

In our study, we show that IT diameter can be reliably measured in $93.1 \%$ of all normal fetuses in the standard mid-sagittal view of the face at $11-13^{+6}$ weeks of gestation. The varying rates were reported in the literature between $87.2 \%$ and $100 \% .^{[6,7,11-15]}$ Fetal position, obesity, gestational age and whether sonographers were obstetricians or maternal-fetal medicine specialists with a particular interest in sonography or not were significantly associated with the success of IT visualization. $^{[7,12,14,15]}$

Different mean IT diameters have been reported by different clinics. ${ }^{[6,16,17]}$ In a prospective multicenter trial from Germany, a total of 16,164 fetuses were examined, and 11 open spina bifida cases were identified at the first trimester screening and mean IT diameter was reported $2.1 \mathrm{~mm} .{ }^{[7]}$ In our study, we reported mean IT diameter $1.83 \pm 0.29 \mathrm{~mm}$. Mean IT diameter increased from 1.6 $\mathrm{mm}$ at $45 \mathrm{~mm}$ CRL to $2.1 \mathrm{~mm}$ with $84 \mathrm{~mm}$ CRL. A prospective study with 1479 cases from our country reported mean IT diameter $1.99 \pm 2.6 \mathrm{~mm} \cdot{ }^{[18]}$ Another study from our country reported mean IT diameter $1.77 \pm 0.4 \mathrm{~mm} .{ }^{[15]}$ This study had lower sample size compared to our data and some CNS abnormalities were not excluded from the normal cases. Peixoto et al. ${ }^{[16]}$ assessed 199 fetuses at $11-13^{+6}$ weeks of gestation in a Brazilian population. Mean fetal IT ranged from $1.6 \mathrm{~mm}$ at $45 \mathrm{~mm}$ CRL to $2.0 \mathrm{~mm}$ at $84 \mathrm{~mm}$ CRL with a mean of $64 \mathrm{~mm}$ CRL. A prospective study with 111 cases from China reported that IT diameter increases from 1.35 to $2.6 \mathrm{~mm}$ at the same gestation with a mean of $65 \mathrm{~mm}$ CRL. ${ }^{[1]}$ 
In our study, we showed that the IT diameter increased linearly with increasing CRL, which was consistent with the previous reports. ${ }^{[6,12,13,19]}$ A weak positive correlation was found between increasing CRL and IT in some studies like our study ${ }^{[11,17]}$ but high correlation was noted in other studies. ${ }^{[6,19]}$ The main difference in our report was the higher sample size than previous reports.

\section{Conclusion}

We evaluated the measurability of the IT during routine first trimester NT and anatomy scanning and presented a nomogram of IT diameter at $11-13^{+6}$ weeks of gestation in our population. This marker can potentially be used for early prediction of cerebral abnormalities and other NTDs.

Conflicts of Interest: No conflicts declared.

\section{References}

1. Welch K, Winston KR. Spina bifida. In: Myrianthopolous N, ed. Handbook of clinical neurology. Vol 50. Malformations. Amsterdam: Elsevier; 1987. p. 477-508.

2. Nicolaides KH, Campbell S, Gabbe SG, Guidetti R. Ultrasound screening for spina bifida: cranial and cerebellar signs. Lancet 1986;12:72-4.

3. Campbell J, Gilbert WM, Nicolaides KH, Campbell S. Ultrasound screening for spina bifida: cranial and cerebellar signs in a high-risk population. Obstet Gynecol 1987;70:24750.

4. Braithwaite JM, Armstrong MA, Economides DL. Assessment of fetal anatomy at 12 to 13 weeks of gestation by transabdominal and transvaginal sonography. Br J Obstet Gynaecol 1996; 103:82-5.

5. Khalil A, Coates A, Papageorghiou A, Bhide A, Thilaganathan B. Biparietal diameter at 11-13 weeks' gestation in fetuses with open spina bifida. Ultrasound Obstet Gynecol 2013;42:40915.

6. Chaoui R, Benoit B, Mitkowska-Wozniak H, Heling KS, Nicolaides KH. Assessment of intracranial translucency (IT) in the detection of spina bifida at the 11-13-week scan. Ultrasound Obstet Gynecol 2009;34:249-52.

7. Chen FC, Gerhardt J, Entezami M, Chaoui R, Henrich W. Detection of spina bifida by first trimester screening - Results of the Prospective Multicenter Berlin IT-Study. Ultraschall Med 2017;38:151-7.
8. Mangione R, Dhombres F, Lelong N, Amat S, Atoub F, Friszer S, et al. Screening for fetal spina bifida at the 11-13week scan using three anatomical features of the posterior brain. Ultrasound Obstet Gynecol 2013;42:416-20.

9. Lafouge A, Gorincour G, Desbriere R, Quarello E. Prenatal diagnosis of Blake's pouch cyst following first-trimester observation of enlarged intracranial translucency. Ultrasound Obstet Gynecol 2012;40:479-80.

10. Iuculano A, Zoppi MA, Ibba RM, Monni G. A case of enlarged intracranial translucency in a fetus with Blake's pouch cyst. Case Rep Obstet Gynecol 2014;2014:9680-9.

11. Chen M, Chen H, Yang X, Wang HF, Yeung Leung T, Singh Sahota D, et al. Normal range of intracranial translucency (IT) assessed by three-dimensional ultrasound at $11+0$ to $13+6$ weeks in a Chinese population. J Matern Fetal Neonatal Med 2012;25:489-92.

12. Adiego B, Illescas T, Martinez-Ten P, Bermejo C, PerezPedregosa $\mathrm{J}$, Wong $\mathrm{AE}$, et al. Intracranial translucency at 11-13 weeks of gestation: prospective evaluation and reproducibility of measurements. Prenat Diagn 2012;32:259-63.

13. Yuksel MA, Arisoy R, Erdogdu E, Imamoglu M, Yayla M, Sen C. Relationship between first trimester visualization of the intracranial translucency and spina bifida. Arch Gynecol Obstet 2015;291:513-8.

14. Fong KW, Dengler J, Toi A, Menezes RJ, Karimzad Y, Okun N. Prospective study of intracranial translucency and the posterior brain in normal fetuses at the 11- to 13 -week scan. J Ultrasound Med 2014;33:1373-9.

15. Lane A, Lee L, Traves D, Lee A. Intracranial translucency assessment at first trimester nuchal translucency ultrasound. J Med Imaging Radiat Oncol 2017;61:185-9.

16. Peixoto AB, Caldas TM, Lasmar LA, Martins WP, Pares DB, Araujo Junior E. Reference range for the fetal intracranial translucency measurement between 11 and $14+2$ weeks of gestation in a Brazilian population. J Matern Fetal Neonatal Med 2016;29:2588-91.

17. Papastefanou I, Souka AP, Pilalis A, Panagopoulos P, Kassanos D. Fetal intracranial translucency and cisterna magna at 11 to 14 weeks: reference ranges and correlation with chromosomal abnormalities. Prenat Diagn 2011;31:1189-92.

18. Kose S, Altunyurt S, Keskinoglu P. A prospective study on fetal posterior cranial fossa assessment for early detection of open spina bifida at 11-13 weeks. Congenit Anom (Kyoto) 2018;58:4-9.

19. Molina-Giraldo S, Perez-Olivo JL, Arias JL, Acuna E, Alfonso $\mathrm{D}$, Arreaza $\mathrm{M}$, et al. Normal intracranial translucency values during the first trimester of gestation in Latin American Population. J Ultrasound Med 2016;10:2231-6. 